\title{
THE PROBLEMATIC NON-WESTERN COSMOPOLITANISM IN AFRICA TODAY: GRAPPLING WITH A MODERNITY OUTSIDE HISTORY
}

\author{
STEPHEN CHAN
}

\begin{abstract}
The question, 'can Africa deal with a postcoloniality without reference to the colonising metropole?' neglects that Africa must deal with many powers that were not colonisers. Dealing with China requires a relationship outside the period of formal colonial rule, and requires a new cosmopolitanism that can be difficult, yet vibrant.
\end{abstract}

Key words: China; Africa; New World Outlooks

My paper is concerned with theoretical debate, but also acts as a series of reflections based on personal experiences and participation in relationships between China and Africa. I am of Chinese origin, but lived in Africa many years and, since 1979, have been travelling throughout the continent-working in war zones, the great city slums, and in high government offices; sometimes, though curiously not often, in universities. I have been seconded to a senior pan-African delegation, led by the Deputy Chairman of the African Union, discussing Sino-African trade in Beijing; and have worked with senior Chinese officials and institutions there, including with the State Council. My longhaired appearance continues to raise eyebrows in Beijing, but is a badge of safe conduct in the slums of Africa-where once I lectured at a community centre on the French philosophical context of Frantz Fanon... but of such things, more later-except to say, at the beginning as a tantalisation, the imagination of the cosmopolitan is often vulgar, even when well-meaning (there have been many enthusiastic solidarities which, to the recipient, are bemusing); but sometimes an imaginative vulgarisation is a means of entry to a truer cosmopolitanism.

By way therefore of working, if colloquial, definition, by 'local cosmopolitanism' I mean when, in any particular local community, the global is appropriated and indeed refracted in local terms that not only make the global sympathetically operational, but does so desirably with such local richness that-its refraction - the global is itself changed, i.e. some form of equity, or at least equal exchange occurs. Equity may be an idealism, as the global context is one of changing hegemonies. The impact of Indian culture and Chinese economic might

DE GRUYTER 
in the world today are cases in point. In the 1960s, with the advent of the global guru industry emanating from India, it was said a spiritual vacuum was filled among the Western young. That was in part the case, but it was part also exploitation of the impressionable. Cosmopolitanism is not necessarily benign. It can certainly be messy and maladroit. And the process in Africa is really in its infancy compared with the relationship between China and Europe. This paper looks at the infant, but hugely problematic, conjuncture of cosmopolitanisms between China and Africa today.

What then does this paper seek to do? It will look at what is now widely known as 'local cosmopolitanisms' and their intersection with 'global cosmopolitanism'. There is an immediate danger here in that the 'global' is hardly global at all. Insofar as it is presumed to be related to norms regarded as universal in the West, predicated on Enlightenment thought, it is a globalism which is contested or paid lip service. China's expanding worldwide reach proposes, without necessarily saying so, an alternative globalism and implicitly alternative norms. But, whereas the West is known to Africa via imperialism and colonialism, reflective knowledge of China and experiential knowledge are recent. In terms of what is 'local', there are of course 54 or 55 states in Africa, with some 2000 languages. There are majoritarian languages to be sure but the confluence of so many linguistic and related epistemological streams - never mind normative streams - makes the term 'local cosmopolitanism' often a grand and casual generalisation.

The paper cannot overcome these problems. It can propose a key principle of equality at the rendezvous of whatever is described, even casually, as the global and local-and that principle is one of equality of experience, norms, and thought processes.

The methodology here is one of telling stories. Everyone says, 'let's tell stories', and then proceeds to theorise mightily the idea and forms of a story, sometimes analysing stories from great literature, but never telling an original story. This paper presents original stories. But this requires a narrator to have original stories to tell. The intersection of different cosmopolitanisms has to be experiential of those of others.

So the paper is finally an exercise in the illustrative. It is not theoretical in the formal sense, but does critique bodies of theory.

\section{International relations and the system}

My home discipline is International Relations. It is a relatively new discipline, founded in 1918 by the idealistic Welsh millionaire, David Davies, and the first chair - the Woodrow Wilson Chair, which still exists-was endowed by him and his family in 1922 (Porter, 1989). Davies was either well ahead of his time, highly idealistic, or eccentric. He proposed an international police force, for instance — an initiative supported only by New Zealand. But the reason such a universalistic idea was rejected, and would still be today, was that the world was configured according to a state system. States were sovereign but somehow cohered through 'concerts of power' into an immutable system. Nothing could be suprasystem, especially not in any coercive sense. The system basically began with the Treaty of Westphalia (1648), which ended the 30 years war which had ravaged and militarised Europe, and was consolidated by the Congress of Vienna (1815) after the defeat of Napoleon. These foundation moments had a huge effect on Henry Kissinger and his lifelong doctrine 
(Kissinger, 1954, 2013, 2014) and, for International Relations (IR), they were the beginning of modernity.

The new discipline rapidly splintered into two main schools, the dominant one being Realism-in which states in the state system projected power-and the one closer to David Davies, albeit in a constantly mutating way, variously labelled Idealism or Pluralism with many sub-labels. But Idealism also assumed the existence of a system in which nonstate actors could have an increasingly important role. The advent, in the late 1960s of a Structuralist school borrowed from international political economy in its neo-Marxist guise; here the overarching international system was a capitalist one with a determining mode of accumulation and hence exploitation and a condition of dependency (Olsen \& Groom, 1991). And, from the late 1980s, gathering steam with the fall of Communism and its monolithic alternative to a purely Western state system, there was what is called a 'normative turn', in which continental philosophy, especially critical theory, was drawn into debate as an enquiry into 'truth', as opposed to an opposition to 'power', although it declared it would speak truth to power in ways not fully explained (Brown, 1992; Chan, 2014b). Here the sense of universalism was Kantian, Enlightenment in Europe, and no one enquired into non-Western ideas on truth.

What IR had to do was to marginalise or peripheralise Area Studies, establish itself as a rival to Comparative Politics, and discard the idea that the particular might have a claim against the universal.

There has been slowly a reaction against that, beginning in 1995 with a seven session series of panels in Paris (Chan, Mandaville, \& Bleiker, 2001) and which has led to a prototypical new school named 'worlding' (Bilgin \& Ling, 2017) and the 'conversion' of leading lights in IR to the possibility of different approaches to conceptualising the system (Acharya \& Buzan, 2010). In all of this, the present author has been active (Chan, 2009b, 2017), but even he would concede that the claims of a monolithic universal still have strong hegemony in IR. If anything in the future might destabilise that it will be the emergence of powerful Chinese discourses on the world-but the Chinese are at this stage concerned to play the game of concepts with what the English in cricket call a 'straight bat' (a game which otherwise utterly perplexes the Chinese - and most of the world...) but which means to play conservatively and slowly accumulate a victory, so slowly that onlookers lose concentration because of the apparent predictability of play.

\section{The challenge of postcolonial studies}

Postcolonial Studies arose at a stroke, courtesy of Edward Said's intervention at the 1989 Silver Jubilee Triennial Conference of the Association of Commonwealth Literature and Language Studies, University of Kent. His challenge was basically against the absorption of literary production from a great swathe of the emerging world into the Commonwealth, something that was post-imperial-but still seen as imperial. Suddenly, the assembled masses resolved to 'decolonise' themselves, and Postcolonial Studies was born- but persisted overwhelmingly to study works written in English. I participated in this conference and it would have seemed an historic moment-except that five years earlier at my alma mater Ngugi wa Thiongo rehearsed what became Decolonising the Mind (Ngugi, 1986), 
which called for the equality to English of other languages. Thenceforth, Ngugi wrote in Kikuyu. But Postcolonial Studies never set out to be a discipline in any other but metropolitan languages, especially English. To the call for linguistic equality came the reply of hegemony (Chan, 2014a).

The compensation was that, being 'post' colonial, the new discipline took swingeing swipes at all things otherwise condescending to the emerging world. It became a mission of angst, addressing the themes of literature in political terms expressing metropolitan guilt. And insofar as imperialism had spread all over the world, this guilt has become a universalist project—but never in Kikuyu and, though using political terms, never with more than a primitive Political Science. Like post-Realist IR, it was the metropole with a consciencebut it was still the metropole. And, insofar as Critical IR at least made great use of what it loosely termed the cosmopolitan $\mathrm{v}$ communitarian debate as its launching ground - a baggy depiction of Kant and Hegel (Thomson, 1992)—it never really, until recently, made it clear exactly what cosmopolitanism was. It was much more successful with communitarianism (Frost, 1986; Linklater, 1998), but the means by which cosmopolitanism was indeed cosmopolitan were never interrogated-especially never asking the question whether the world system was now cosmopolitan by dint of imperialism. And, even if admit this, it hesitated to enquire how cosmopolitanism could wear a local face.

This latter question has been rarely asked by most disciplines. Insofar as IR has belatedly decided to give some little thought to it—and not really very directly until 2010 - it was still thought in its formative stages. It was open-ended to be sure, and 'progressive' in terms of its implied sense of retribution: those once marginalised will soon be those globally capable of accomplishing the marginalisation. In the words of international political sociologist Jeffrey Alexander:

\begin{abstract}
So it will be with sociology. We are fortunate to be alive in the era when the extraordinary modernization of non-Western societies is allowing them to challenge Western hegemony for the first time in some 500 years. Eventually, this process of multiple modernities is bound to challenge, not only Western economic prowess and military might, but its hegemonic sociological theories and methods. When these Chinese or Indian or Korean and South African or Russian thinkers do throw down their theoretical and methodological gauntlets, however, they will do so not as indigenous species. Their works will be products of centuries of intense intellectual globalizing (Alexander, 2018).
\end{abstract}

In other words it will be cosmopolitan by dint of admixtures and integrations of ideas, but with a shift in the balance of power as to who does the integration and how.

Insofar as before the 2000s, IR sought to deal with different conceptual and analytical views of the global-who owned the global and who was right or wrong to own it-it advanced a sub-system hierarchy called 'levels of analysis'. Difference was accommodated by discerning at which level of the system it arose- not from what alternative proto-system it arose. The system was unchanged, although viewed differently from level to level, i.e. state alliances, states, sub-state actors, actors unconnected with state apparatus (Hollis \& Smith, 1981). None of these sought to impose the local upon the global, but sought to interpret and inflect the global with elements of the local. The local remained a subsidiary, capable of analysis and concept, but without power or capacity to change in any decisive manner the global system. 


\section{Towards a local cosmopolitanism}

The problem with much Western theory on local cosmopolitanism is that it is precisely rendered in privileged places. Van Assche and Teampau looked at three European cities. Their book first illustrates the interplay between networks and narratives in the construction of cosmopolitan communities in Trieste, Odessa and Tbilisi. Each has a past more cosmopolitan than the present and each uses that cosmopolitan past to guide them towards the future. The authors offer a unique perspective on cosmopolitanism, examining the ways it is constructed and reconstructed on the small scale in an ongoing process of matching the local with the global, a process entailing mutual transformation. Based on a wide range of literatures and a series of case studies, they analyse the different versions and functions of cosmopolitanism (Van Assche \& Teampau, 2015).

In each case, however, there was the a priori sense of being European, of being part of a European long duration, and above all of being able to interrogate both the local and pan-European aspects of that in recorded text, with always an articulated, written and preserved, curated local version to place against any rendition of the wider European-that wider Europe having, in any case, in its own varied records, recorded traces of Trieste, Odessa and Tbilisi. Each city has always sat at a crossroads. The global came to it and was as much received it on its own terms as it was influenced or perhaps conquered from time to time by it.

None of that pertains to Africa. So that the history of local cosmopolitanism and its standing up to the global is recent, is recently recorded in a foreign tongue, and has a local discursivity that cannot be as extensive-even if it is felt as deeply-as the three European cities mentioned above. The very advent of cities to act as melting pots of both the local and 'global' has been new to most of Africa-with the conspicuous exceptions of course of Islamic West African cities, Timbuktu, Addis Ababa and, at a stretch (i.e. stretching into history as legend but leaving no written trace), Great Zimbabwe. The foundations of a discursivity therefore are not for the most part archival and officialised as history. So that when Appiah speaks of a project, drawing from the $4^{\text {th }}$ century Cynics view of cosmopolitanism, i.e. one with the possibility of commonality rather than difference, and necessarily drawing on a written discourse (often conflicting) on ethics ever since, he is speaking of an idealism whereby Africa inhabits a memory of the ancient recorded world by courtesy and not by historical default (Appiah, 2007).

And even if Africa inhabited written space, would that, in itself, have been enough? Can there not be hegemonies pre-emptive of other local cosmopolitanisms expressing themselves on their own terms? For agreement has to be reached as to what those terms might be, with the question as to whether un-rancorous agreement could be achieved in a continent of 55 states and 2000 languages.

And, if fast forward to the present day, new traps in an age of easy communication and intercourse, open up. Two examples from popular culture show how impositions work in a form of exotic (or Marvellous) exotica. 


\section{Black Panthers do not speak Xhosa}

Black Panther became an iconic film. The question is 'iconic for whom?' In fact, the film is in a direct way related to the argument between Ta-Nehisi Coates and Cornel West. ${ }^{1}$ West, a celebrated philosopher-with an early impressive opus on philosophic pragmatism—said that the fractures of society have more to them than the dispossessed being simply black. Coates stressed, certainly in the US context, the centrality of blackness in all matters discriminatory. He was, of course, the writer of the Black Panther Marvel Comic-as well as an extremely thoughtful journalist—but the film of his comic makes of African blackness an undifferentiated mish-mash that, all the same, underwrites precisely West's point that economics, leverage and power, strategies of cooperation and confrontation, global structures, have something to do with race relations and, in the case of the film, international relations.

It's a mish-mash despite its effort to use African language. Xhosa, a widespread language in South Africa, known for its clicks, is spoken well in the film. Except that, suddenly, from time to time, a Swahili word or phrase suddenly intrudes. That's careless and lazy. It's like mixing a bit of Finnish with Greek and claiming it's all European. But perhaps the Swahili is a useful pointer as, in fact, there actually aren't too many black panthers in Africa. Outside South America, where they are members of the jaguar species, panthers are black leopards that live mostly in Asia, with small populations in Ethiopia and Kenya. Kenya is one of the Eastern African countries where Swahili is spoken as it is in minority parts of Ethiopia. But no black panther has ever existed in South Africa where Xhosa is spoken. Ancestors who speak Xhosa and who have the powers of a panther are gobbly-gook.

Apart from colour, black jaguars and black leopards are very different. The panthers glimpsed in the film are jaguars-South American.

The idea of a hidden mountain kingdom in South Africa immediately resonates with the fact that Lesotho is exactly a largely unknown such kingdom-and, in fact, I kept scanning the Argentinian landscape hoping it was in fact Lesotho, a country of great but devastated beauty; but in Lesotho they speak Sesotho-which is not Xhosa by a long shot.

Wakanda is most reminiscent of the El Dorado of the dreams of Spanish imperialists. There would be a city of gold somewhere. And the whole of the film resonates with the tropes of imperialism-from which Wakanda has supposedly freed itself. But the very name, Wakanda, was first used by Edgar Rice Burroughs, the inventor of Tarzan-very like a Marvel character-but who hardly represented an accurate picture of Africa. Ghost Who Walks, Panther Who Walks, the parallels are unflattering.

But the capital of Wakanda is indeed a hidden El Dorado, not of gold, but of technology based on the fictional mineral, vibranium. To be fair, vibranium keeps popping up in a range of Marvel Comics, but it has two chief characteristics in Black Panther: (1) every single technology achieved by this African state owes to vibranium; without it they are reduced to nothing; with it, Wakanda is great-suggesting people got lucky in the foundation of their development, as no one else accidentally found themselves sitting on top of concentrated

1 https://www.vox.com/policy-and-politics/2017/12/22/16802900/tanehisi-coates-cornel-westtwitter 
deposits of the stuff; (2) the Wakandan scientists beneficiated (processed, manufactured it from its raw state) it themselves.

This is the absolute key point of the film, and it is a very good one. And it is the key point of Cornel West. Much of Africa's under-development is because multi-national mining corporations extract the continent's minerals and raw materials- they might or might not pay a fair price for it, I think far too often they don't-but then they beneficiate it and make huge profits from the manufactured product, and none of the profit from that comes back to Africa. The African state that develops the industrial capacity to achieve the manufacture of its raw materials will become much richer than one which simply sells its assets raw. But huge industrial combines seek to keep manufacture in the USA, in Europe, in China. Jobs and economies depend on it. When Middle Eastern countries began refining their own oil, it caused a huge outcry. That was the prerogative of Exxon Mobil and the rest of what were then called the Seven Sisters-all corporations in the West. That protected black workers in the West as well.

If the take-home from Black Panther is that you've got to do it yourself, it is a wonderful take-home-but industries and their workers will indeed suffer elsewhere. That is why neither right nor left, corporations nor trade unions, bosses nor workers, want an industrialised Africa.

If, by some wonderful movie-magic chance, all the new African industries could be ecologically clean, that would be a fantasy come true. But industrialisation is messy, as China has shown. And 55 separate African countries are not going to come up with a common industrialisation and ecologisation platform and policy. And, as the US withdraws from the Kyoto Protocol, even those loose but useful targets and limits will lose their appeal to other countries.

\section{The kung fu masters of the slums}

In 1980, as the result of a bet with local companions, I walked the full length of River Road in Nairobi, and back, without being assaulted. It is somewhat gentrified now but was then the key danger spot of central Nairobi and foreign visitors were urged to avoid it. Robberies with violence were its reputational markers. The secret lay in the Casino Cinema, at one end of River Road, then the seedy and grubby home of Grades B and C kung fu films from Hong Kong. They were uniformly awful—but the heroic swordsmen and kung fu fighters in each and every one of them had uniformly long black hair. So I would be greeted as I walked down River Road-and elsewhere in Africa-with 'Good Afternoon Sifu (master)' and 'I love your Shaolin hair, Sifu', and 'Can you teach me kung fu, Sifu?' Now, in fact, I couldand from the very next year I did, and turned a blind eye to my own shamelessness in trading off an ersatz cultural stereotype-compensated by the knowledge I had actually been taught numerous 'oriental arts' to high level (Chan, 2011) and could indeed blame an insidious but now convenient family lineage (Chan, 2015).

But I began teaching in the slums of Africa because I discovered a wonderful sense of cultural imagination. Local youngsters with athleticism and careful eyes would watch the Hong Kong films over and over again, memorising and learning the moves, neglecting the basic fact that the moves were cinematic more than authentic, declare themselves Sifu and 
open schools in bare patches of dirt or ramshackle community halls. They even devised elaborate rituals of courtesy as cross-cultural politesse-exaggerated but in fact largely correct. But I began teaching as I thought they might as well get the real thing-rather than simply a participant exotica - and a gigantic people's republic of kicking one's way out of the ghetto was inaugurated and continues to this day with thousands of students taught on an entirely charitable basis.

What I discovered was a local cosmopolitanism, yes? But it was founded on a fiction, on an impersonation, on an exotica, on nothing intellectual, indeed often on no 'knowledge' at all. But it became embedded in the local.

Both the Kenyan example, and the black American example of seeking to impose a metropolitan sense of cosmopolitanism upon an imagined Africa are false-but they give a sense of cosmopolitanism embedded into the local. Later in this paper I shall say that this sort of sensibility leads to vulgarisation. For now, a further digression leads us again to what is not 'out there', despite its seeming to be so from 'in here'.

\section{Cuisine in the midst of war}

In 1980, January to the beginning of March, the independence election campaign took place in Zimbabwe. The guerrilla parties were allowed to campaign, and their soldiers were gathered into camps to observe a ceasefire. It was all, however, very uneasy. Securing confidence from warring parties in the process was much harder than securing access for observers (Chan, 1985). I was one such observer and, in terms of the Lancaster House Agreement that had agreed the process, liaison could only be conducted by Lt Colonels or people with Lt Colonel status. Since this rank didn't exist in the guerrilla armies (Commander was the approximate equivalent) and since (like me) those anchoring the observation had not held military commissions, we were all jumped up willy-nilly to 'liaison ranks' of Lt Colonel. So it was, one day, in some forbidding scrubland I was waiting to meet two of the liaison officers from Robert Mugabe's faction. I think, when they finally appeared, they had been more nervous than me, until they laid eyes on me and instantly beamed - a Chinese person (!) - and they immediately reached into their webbings (vest apparatus used to carry ammunition and equipment) and pulled out chopsticks. "Ah, your people helped us when no one else in the world would." It turned out they had trained in Tanzania under Chinese instructors, and some of their senior colleagues had trained in China itself. "So tonight we will cook for you! We will cook Chinese, just as we were taught!"

But cuisine aside, assistance with liberation was seen and rendered in modern termsthere was a vicious war fought with modern weapons-in terms of solidarity, rather than interrogating and incorporating beyond a functional point 'difference' and otherness.

Africa, so immersed in its own recent history of liberation and decolonisation (Ghana's independence in 1957 is still very much within living memory; Zimbabwe's in 1980 means that a 30 year-old Lt Colonel then is a 'youthful' 68 year-old General now) that Chinese, Soviet or other help notwithstanding, there is generally no concentration upon, or deep knowledge of China's own battle against imperialism-key stages of which preceded or ran in parallel with African anti-colonial consciousness and later struggle. The early kung 
fu films often depicted Chinese patriots fighting against Japanese occupiers-but no one even once asked me why the Japanese were in China, let alone whether it was a project of colonisation undertaken unilaterally or with other powers; let alone why those other powers were Western, and how Japan had secured entrance into the Western club but China had not. No one knew about the terrible Opium Wars, in which Britain was content to force an entire nation into becoming drug addicts for the sake of trading profit, or how Japan and the Western powers had divided up the coastal cities and other provinces among themselves; how, during World War II, Japan had established a puppet government; or how the Chinese nationalist struggle went through various stages-mystic and militarised as in the Tai Ping and Boxer uprisings; republican under Sun Yat Sen; internecine between the forces of Chiang Kai Shek and Mao Tse Tung; and finally victoriously successful under Mao, who then made catastrophic mistakes in development strategy (Mitter, 2004). When I explain this to my students in Africa, they are wide-eyed that there even was a liberation struggle outside Africa. There is vague knowledge of Ghandi and India, no knowledge of Simon Bolivar and Latin America, no knowledge of the Maori war against white land-acquiring settlers in New Zealand.

\section{Towards a local vulgarisation}

If a widespread ignorance leads to a vulgarisation of both China and the perceived 'Chinese project' in Africa, and at best resorts to an exotica, then the ignorance in China towards Africa can lead to an outright vulgarisation. If not vulgar, then condescending and patronising - although these terms are not exactly what they connote in English. An example, and then an explanation, from when I sat with an African ministerial delegation in Beijing and, to an extent, both sides were talking past each other. After the first day I was approached privately by a member of the Chinese side: "We see, Professor Chan that you really want to help the Africans. But, surely, you could help them even more if you sat with us insteadbecause surely you will appreciate how much the Chinese want to help them."

The explanation lay in the Confucian sense of guanxi, a term which has no exact translation, being as much a concept and an unspoken practice as a word-but, loosely, it can be rendered as 'reciprocation' (Chan, 2009a). Whereas all contemporary Western concepts of society, and social practice, are premised on a horizontal base — democracy and equalityguanxi is vertical and hierarchical. This is not in a dictatorial sense in its conceptual foundations, although it easily becomes so, but involves dynamism among five sets of pairings-from emperor to subject, to husband and wife, to older brother to younger brother, and only in friend to friend is there an assumed equality. But each pairing is transacted by the dynamism of reciprocity: the junior is obliged to show respect to the senior, but the senior must provide benefit to the junior. This is in a way lovely, except for two things: it explains why the basic Chinese model in Africa involves the front-loading of benefits (this is an obligation) and even the taking of huge risks for upstream rewards that may never materialise; but it also means a fixed relationship; the junior can never overtake the senior except by breach of protocol and the orderly nature of the universe. Thus, when the Chinese said to me that I could help the Africans far more if I negotiated on the Chinese side, it was as if a statement of the natural and the obvious was being made. 
The vulgarisation of this, added to the same type of ignorance towards African history as Africans often display towards Chinese history, often devolves into (a) an arrant racism, (b) an assumption that Chinese domestic practice, simply because it is Chinese, can be exported elsewhere, especially to under-developed locations, and (c) that the Chinese are superior to everyone else, black and white, by dint of longer and deeper civilisation, and by the sheer prodigious nature of the Chinese work ethic - this latter virtue providing its own reward in terms of gains over others.

The centralisation and elevation of what amounts to an ethos-with sophisticated and vulgar renditions - is becoming more apparent in real time with the growing authoritarianism of the Xi Jinping regime and the concentration on his own personality and way forward. Xi becomes the 'emperor' at the top of the hierarchy. He will survive if he channels continuous benefits downwards, reaping acknowledged control in turn. What this means for foreign policy can be seen in China's militarised claims to surrounding disputed islands and other territories. What it will mean for Africa may be seen in Robert Mugabe's fruitless efforts to secure Chinese help in universal debt relief-because, as well as respect and obeisance upwards, there must be discernible responsibility in those below. Mugabe never 'got' that. He never outgrew that moment when his soldiers knew how to eat with chopsticks. What it means is that accommodating the Chinese in Africa, whether their behaviour is manifest in the most vulgar behaviour of private corporations or in the condescension of public and official assistance is that it is almost inevitable that a dysfunctional local cosmopolitanism supersedes the space that a proper local cosmopolitanism would seek to inhabit. And, particularly in the behaviour of some private Chinese corporations, what is represented as Chinese is not high culture but its bastardisation into racism.

\section{Navigating the other as a cosmopolitan modality}

In a global world, what is local is necessarily caught up with globalisation and, with the advent of the new China, with competitive globalisations; navigating all this in local terms may be desirable but not fully possible; inflecting the global/s with the local, setting terms, may be possible if understanding of the global Other/s is accomplished.

In the case at least of China, we relate now two examples from Zambia. The first concerns the election to the presidency of Michael Sata in 2011 after earlier failed attempts. In one of those, in 2006, he had expressed virulent anti-Chinese sentiments-accusing Chinese interests of exploitation and discrimination. Wisely, on his election, knowing he had prejudiced any sense of his own even-handedness, he entrusted the 'Chinese portfolio' to his vice president, Dr Guy Scott. Scott, a highly successful commercial farmer and computer scientist, adopted a cerebral approach and summonsed Chinese mine owners and managers to a series of seminars on Zambian labour law-conducted in Chinese. (One of the key translators, the film-maker Hangwei $\mathrm{Li}$, is now my $\mathrm{PhD}$ student.) And, by dint of sympathetic medium and patient tutoring-with of course a degree of 'hard power' in reserve as Michael Sata's name was casually invoked at difficult moments-labour relations between Chinese corporations and Zambian workers began to improve.

Another example, involving again the Zambian mining sector, concerned union frustration that they could not secure from Chinese employers up to 12 fully-paid annual 
'funeral days' for each employee; this was met on the Chinese side by bewilderment as to why 12 such days were needed. It was surely an example of Zambian 'laziness' - until it was patiently pointed out that Zambian mine workers constituted what has been called a 'labour aristocracy' (Burdette, 1988) by virtue of being the majority of those employed in the formal sector. As such, and within the extended family rubric of almost all Zambian society, despite some 72 ethnic groups, each worker probably fed some 30 people, and was looked to for help in emergencies from an even wider network of relatives and neighbours.

Zambia was still enduring the effects of the HIV/AIDS pandemic, with inadequate medical facilities to cope, and some initial reluctance to seek out treatment, and so deaths in the extended family were common and numerous. When this was pointed out to the mine owners and managers - together with the culturally resonant factor that, in providing the costs for the funerals, and by being present at each of them, the salaried employee could not 'lose face' by providing a wake that was meagre. Almost immediately, there was breakthrough in the hitherto deadlocked talks, and the funeral days were given (Nakana, 2013).

\section{Rhodes must fall - but Rhodes fell, so did zuma and many others. What rises?}

The huge campaigns among students in South Africa resulted in a statue being rehoused in a non-public space. Stone is resonant in public spaces, of course. Their conditions at the universities did not improve, fees might fall then rise again, the government has no money, and even if it did the abolition of a statue would not ensure its wise expenditure. Insofar as the statue was a symbol of white privilege the protests that made it a target reduced race relations in South Africa to a binary discourse, to a construction of dyads. In International Relations, James Rosenau in a hugely influential book did the same-reducing policy choices to a (complex) series of opposing descriptors and definers (Rosenau \& Hoggard, 1974). US foreign policy during the Cold War was precisely in that mould, especially at the time of the Communist witch-hunts, and its latest iteration marks a new era in utmost lack of sophistication in addressing the world. It can be white against black, it can be a clash of civilisations (Huntington, 1996), it can be good versus bad. And this is precisely where the problem is identifiable: when black and white become norm-laden and speaks as if good and bad, speaks in synonyms and speaks automatically of condemnation and the impossibility of dialogue. Discourse, if one may speak of its crude iterations, adopts norm-laden dyads with the construction of the 'correct' norm involving opposition, exclusion and objection.

In terms of the history of Apartheid, it leaves out coloureds, Asians and Chinese. The Chinese played an ambiguous role to be sure. Japanese were, at one stage, given honorary white status but Chinese were not. Chinese were often seen to be seeking advantage by appearing close to 'whiteness' - but at the 1955 Congress of the People in Kliptown, Soweto, where the Freedom Charter was adopted and the fightback against Apartheid formally began, the 3000 delegates, smuggled in from all other South Africa, were fed by a Jewish butcher and Chinese greengrocer. I stayed in Kliptown several times-the most underdeveloped part of Soweto, untouched by ANC attention, the home of notorious knife fighters, and voting far from Western Cape for the opposition Democratic Alliance-and every time I was greeted well with the legend of the Chinese greengrocer. 
And of course, in today's South Africa, with its lack of equality, service delivery and general eptitude, xenophobic communal riots erupt. And these involve South African black and other-African black. I would go to these places and ask, "but how can you tell?" "We can sense the otherness. They are not of us." But sometimes they certainly could not tell. But insofar as they were African and black they would have suffered discrimination if the descendants of Rhodes had reached as far as their countries-which, in the case of Zimbabweans, it did.

Insofar as good and bad have also been crudely related to needing money (and is therefore exploited) and having money (thus exploiting), black and white become descriptors that automatically ascribe behaviour within a crude political economy. When applied to the Chinese, it allows a vulgarisation to match Chinese vulgarisation. When applied to fellow Africans it simply becomes crude — but no cruder than when applied to other groupings.

Having said that, white history, even though only in its local experiential form, is known in Africa. South Africa is of course well known-this being conveniently through probably not fully accurately seen as a direct legacy of white Apartheid insularity-as being unknowledgeable about the rest of Africa. Films about alien invaders as Nigerian cockroaches may be an extreme example-except that it had to be forcefully pointed out by Nigeria in an almost diplomatic incident that the chief cockroach bore the name of one of the country's most respected former political leaders. Who knew? In terms of the Chinese, China is also outside local white-laden history except in its mythical cinematic form. This is despite decades of modern Chinese involvement in Africa, the assistance to Zimbabwe in its war of independence being only one case in point. The Chinese assistance to Zambia in the building of the Tazara railway, and a host of other expensive and non-profit infrastructure projects since the first days of independence are unknown (Chan, 2013; Brautigam, 2009). Chinese migrations to Africa in the pre-independence period brought inter-marriage (prohibited of course in South Africa) and leaders in the post-independence period-Gabon's Jean Ping who became Chairman of the African Union being a key example. All this being largely unknown in South Africa, the latter day stage of Chinese economic penetration rankles without mitigation or context, and fits into a monied/racist exploiter/exploited jointstereotype allied to an unproblematised and vulgarised Otherness.

\section{Warnings}

Let us dwell momentarily on South Africa. Primarily through the advocacy of Desmond Tutu, and with eminent dignitaries with superb moral and jurisprudential credentials (such as Albie Sachs) in full participation, there was created after Apartheid a Truth and Reconciliation Commission. By confessing the crimes of the past and by professing remorse, forgiveness and inclusiveness were offered. It was regarded as a huge moral triumph and as an expression of a togetherness that was meant to be the core ethos of Ubuntu-despite the fact that Ubuntu had hitherto been a vague and generalised term. It has been more precisely articulated since. It certainly took the nation over a chasm that a rainbow bridge by itself could not have done.

There is one problem here: it was operationalised and forgiveness was accorded by an elite panel of persons, precisely like Albie Sachs. It was forgiveness and inclusiveness 
from on high. It was accepted by and large, but did not prevent, a single generation later, in the Rhodes must Fall campaign, a sense of unfinished racial business. Forgiveness and inclusiveness did not bring equality.

People also look at the Rwanda Gacaca courts as another model of forgiveness and inclusiveness (Clark, 2011). Conducted throughout the country at local levels, they seem at first glance like miniature truth and reconciliation commissions. But they are not. They keep the peace by preventing and absorbing the drive towards revenge for the genocide, but they have also been perpetuated by the government in Kigali precisely as a means of social control. What seems a very local cosmopolitanism is in fact an instrumentality of state from the highest level.

Yet, looking casually at these two examples, one may think-as we search perhaps for desiderata, alternative systems of value to match Western metropolitan cosmopolitanism-a far better term perhaps than global cosmopolitanism-that we have found examples of such. But we cannot be conducting this work without interrogation.

\section{The task ahead: Achieving a cosmopolitanism}

Basically, local cosmopolitanism, indeed cosmopolitanism of any sort_-it being increasingly difficult if not impossible to separate the local from the global or even to ascribe convincing even if permeable borders-requires a lot of hard work. On both sides. The Zambian example of patient trade union and mine management negotiation, each side learning about the other, is a case in point; and the patient explanations about labour law, conducted sympathetically in Chinese and emanating from the Vice President's Office, again in Zambia, illustrates what high-level hands-on work can do.

In Angola, as Lucy Corkin in her ground-breaking study has demonstrated, local carefully considered pushback against Chinese positions can lead to significant results and Chinese accommodation of the local (Corkin, 2016).

But there is the issue precisely illustrated in early primitive form by the kung fu films, and that is the growing projects of soft power from the Chinese in Africa. Global Max Media, a private corporation (but, as with all large private Chinese corporations, with party or governmental inputs), is now operating 10 local language platforms for broadcasting and other media in Africa, is screening on its television channels Chinese soaps, is hosting film festivals for directors of both continents, and is essentially projecting a new China with both romanticised and, in the soaps, deliberately trivialised domesticities and concerns. This is not an original approach-the influence of Brazilian soaps in Angola, both Lusophonic countries, projecting an alternative metropole to that of Lisbon, is a case in point-but the scale of Chinese media operations and plans means a cosmopolitanism that is virtual, fictional, casual, and influential all at once.

African projection of soft power back is in its infancy. Probably the one film to have caused a sort of pro-Africa stir in China was Black Panther and, as noted strenuously above, that was not at all African. Curiously, African acolytes and students at the Shaolin monastery martial arts schools in China have made a specialist breakthrough. The sight of Africans performing the complex movements expertly causes rethinking of basic (and base) assumptions. It causes a "why... they are as good as us" moment. 
Mandela was celebrated as an almost archetypical sage of infinite patience, emerging from decades in prison to lead a country with infinite kindness. And the Chinese have in the past attempted, somewhat clumsily, to recognise the importance of African thought. Mao waited till the 1973 visit of Zambia's Kenneth Kaunda to Beijing before announcing the new Chinese 'Three World Theory', crystallised into its final form by the astute and acute wisdom of the Zambian philosopher-President (Chan, 1985b). It was hardly convincing, but it was at least an effort.

Basically, each side needs to bring the other into its history. An African film depicting local polite society receiving the Chinese explorer, Zheng He, who landed with his great fleets off the East African coast more than once in the 1400s, would help do the trick. His were scientific expeditions. The legends are that he managed to get a living giraffe back to China to show the emperor the wonders of Africa. But, somehow not often remarked, Zheng He was a Muslim — so there was a point of engagement in what are now Somalia, Kenya and Tanzania; a point where local and global cosmopolitanisms coincided 700 years ago.

\section{One final story that turned out not to be kung fu}

In 1993 I was in Asmara, Eritrea, as the country was about to conduct its referendum as the final step towards full independence from Ethiopia. I was training the embryonic Ministry of Foreign Affairs and the first cadre of diplomats. One day I was walking the streets and two youngsters, not quite teens, fell in alongside. They spoke some English and one said, "only the masters can wear hair like that." I thought he was referring to kung fu movies where the heroic fighters have long hair. But he wasn't. It became clear he meant I had the freedom to wear my hair unconventionally long. The new government had already begun to impose a code of proper and sober behaviour. It had begun to impose control-mastery. Only a master could have freedom.

When we speak and write about cosmopolitanism, without fully understanding China or the part of Africa to which we refer, we must speak at least of equality. That means not imposing our romanticism, our desiderata as elements that denote an equality between 'them' and 'us'. We must not talk in grand generalities-generality is a form of condensation. It can make great complexities trivial and compressed. So this paper has told stories where there were some intersections based on equality and appreciation. That is the only starting point.

\section{References}

Acharya, A., \& Buzan, B. (Eds.) (2010). Non-Western international relations theory: Perspectives on and beyond Asia. New York: Routledge.

Alexander, J.C. (2018). Local cosmopolitanism. Global Dialogue, 8(1). http://globaldialogue.isasociology.org/local-cosmopolitanism/

Appiah, K. A. (2007). Cosmopolitanism: Ethics in a world of strangers. London: Penguin.

Bilgin, P., \& Ling, L.H.M. (Eds.). (2017). Asia in International relations: Unlearning imperial power relations. London: Routledge.

Brautigam, D. (2009). The dragon's gift. Oxford: Oxford University Press. 
Brown, C. (1992). International relations theory: New normative approaches. New York: Harvester Wheatsheaf.

Burdette, M. (1988). Zambia: Between two worlds. New York: Routledge.

Chan, S. (1985). The Commonwealth observer group in Zimbabwe: A personal memoir. Gweru: Mambo Press.

Chan, S. (1985b). The rise and fall of the Chinese Three World Theory: Chinese foreign policy and Africa. The Round Table. 296.

Chan, S., Mandaville, P., \& Bleiker, R. (Eds.). (2001). The Zen of international relations: IR theory from East to West. London: Palgrave Macmillan.

Chan, S. (2009a). A Chinese political sociology in our times. International Political Sociology, 3(3).

Chan, S. (2009b). The end of certainty: Towards a new internationalism. London: Zed.

Chan, S. (2011). The oriental martial arts as hybrid totems, together with Orientalizing Avatars. In D. S. Farrer \& J. Whalen-Bridge (Eds.), Martial arts as embodied knowledge. Albany: SUNY Press.

Chan, S. (2013). The morality of China in Africa: The Middle Kingdom and the Dark Continent. London: Zed.

Chan, S. (2014a). The limits of guilt and guiltlessness: The postcolonial metropole and postcolonial literature. European Review of International Studies. 1.

Chan, S. (2014b). Untruthful Mandarins and Mandarins of truth. Focus, 72.

Chan, S. (2015). Stephen Chan discusses the life of Wong Wah Yue. Kung Fu Tea.

https://chinesemartialstudies.com/2015/08/02/prof-stephen-chan-discusses-the-life-of-chan-wong-wahyue-warlord-era-swordswoman-village-militia-member-and-grandmother/

Chan, S. (2017). Plural international relations in a divided world. Cambridge: Polity Press.

Clark, P. (2011). The Gacaca courts - Post-Genocide justice and reconciliation in Rwanda. Cambridge: Cambridge University Press.

Corkin, L. (2016). Uncovering African agency: Angola's management of China's credit lines. Abingdon: Routledge.

Frost, M. (1986). Towards a normative theory of international relations. Cambridge: Cambridge University Press.

Hollis, M., \& Smith, S. (1981). Explaining and understanding international relations. Oxford: Clarendon Press.

Huntington, S. P. (1996). The clash of civilizations and the remaking of world order. New York: Simon \& Schuster.

Kissinger, H. (1954, 2013). A world restored: Metternich, Castlereagh and the problems of peace. Indianapolis: Echo Point.

Kissinger, H. (2014). World order: Reflections on the character of nations and the course of history. London: Allen Lane.

Linklater, A. (1998). The transformation of political community. Cambridge: Polity Press.

Mitter, R. (2004). A bitter revolution: China's struggle with the modern world. Oxford: Oxford University Press.

Nakana, S. C. (2013). Chinese capital and African labor in Zambian mining, 1997-2008. (PhD thesis), Graduate Institute Geneva.

Ngugi, wa T. (1986). Decolonising the mind: The politics of language in African literature. Oxford: Heinemann.

Olsen, W.C., \& Groom, A. J. R. (1991). International relations then and now: Origins and trends in interpretation. London: Routledge.

Porter, B. (1989). David Davies: A hunter after peace. Review of International Studies, 15(1).

Rosenau, J. N., \& Hoggard, G. D. (1974). Foreign policy behavior in dyadic relationships. In J. N. Rosenau (Ed.), Comparing foreign policies: Theories, findings and methods. Beverley Hills: Sage. 
Thomson, J. (1992). Justice and world order: A philosophical enquiry. London: Routledge.

Van Assche, K., \& Teampau, P. (2015). Local cosmopolitanism: Imagining and re-making privileged places. New York: Springer.

Politics and International Studies

SOAS

University of London

London,

10 Thornhaugh Street

United Kingdom

WC 1H OXG

Email: sc5@soas.ac.uk 